\title{
In Vivo and In Vitro Evaluation of the Protective Effects of Hesperidin in Lipopolysaccharide-Induced Inflammation and Cytotoxicity of Cell
}

\author{
Rasha Al-Rikabi ${ }^{1}$, Hanady Al-Shmgani ${ }^{1, *}$, Yaser Hassan Dewir ${ }^{2,3, * \mathbb{C}}$ and \\ Salah El-Hendawy ${ }^{2,4}$ (D) \\ 1 Biology Department, College of Education for Pure Science/Ibn al-Haitham, University of Baghdad, \\ Baghdad 10071, Iraq; rasha_fadhil@yahoo.com \\ 2 Plant Production Department, College of Food and Agriculture Sciences, King Saud University, Riyadh \\ 11451, Saudi Arabia; shendawy@yahoo.com \\ 3 Department of Horticulture, Faculty of Agriculture, Kafrelsheikh University, Kafr El-Sheikh 33516, Egypt \\ 4 Agronomy Department, Faculty of Agriculture, Suez Canal University, Ismailia 41522, Egypt \\ * Correspondence: hanadysalim@yahoo.com (H.A.-S.); ydewir@ksu.edu.sa (Y.H.D.)
}

Academic Editors: Hosam O. Elansary and Agnieszka Szopa

Received: 3 December 2019; Accepted: 17 January 2020; Published: 22 January 2020

\begin{abstract}
Background: Plant flavonoids are efficient in preventing and treating various diseases. This study aimed to evaluate the ability of hesperidin, a flavonoid found in citrus fruits, in inhibiting lipopolysaccharide (LPS) induced inflammation, which induced lethal toxicity in vivo, and to evaluate its importance as an antitumor agent in breast cancer. The in vivo experiments revealed the protective effects of hesperidin against the negative LPS effects on the liver and spleen of male mice. (2) Methods: In the liver, the antioxidant activity was measured by estimating the concentration of glutathione (GSH) and catalase (CAT), whereas in spleen, the concentration of cytokines including IL-33 and TNF- $\alpha$ was measured. The in vitro experiments including MTT assay, clonogenity test, and sulforhodamine 101 stain with DAPI (4', 6-diamidino-2-phenylindole) were used to assess the morphological apoptosis in breast cancer cells. (3) Results: The results of this study revealed a significant increase in the IL-33 and TNF- $\alpha$ cytokine levels in LPS challenged mice along with a considerable elevation in glutathione (GSH); moreover, the catalase (CAT) level was higher compared to that of the control group. Cytotoxicity of the MCF-7 cell line revealed significant differences among the groups treated with different concentrations when compared to the control groups, in a concentration-dependent manner. Hesperidin significantly inhibited the colony formation of MCF7 cells when compared to that of control. Clear changes were observed in the cell shape, including cell shrinkage and chromatin condensation, which were associated with a later apoptotic stage. (4) Conclusion: The results indicate that hesperidin might be a potential candidate in preventing diseases.
\end{abstract}

Keywords: Hesperidin-inflammation; hesperidin-antioxidant; lipopolysaccharide; MCF7 apoptosis

\section{Introduction}

Flavonoids are groups of natural polyphenolic structures with diverse activities [1]. Hesperidin (HSP; $\mathrm{C}_{28} \mathrm{H}_{34} \mathrm{O}_{15}$ ), an active flavonoid abundantly found in citrus fruit, has various biological properties. In HSP structure, the aglycon (hesperetin or methyl eriodictyol) is bonded to rutinose [6-O-( $\alpha$-1-Rhamnopyranosyl)-D-glucopyranose] and/or [6-O- $(\alpha-1-R h a m n o s y l)-D-g l u c o s e]$, as a disaccharide [2]. Hydrolysis, demethoxylation, dehydration, dehydrogenation, demethylation, glucuronide binding, sulfate binding and $\mathrm{N}$-acetylcysteine binding are considered the main types of HSP metabolism in rats [3]. Oxidative stress can occur as a consequence of imbalance between 
free radical and antioxidant in the cell, where proteins, lipids, DNA and other important molecules are damaged [4]. The strong relationship between inflammation and tumor and cancer progression has been reported [5]. The free radical scavenging activity by natural flavonoids is attributed to hydrogen donation from hydroxyl groups. HSP acts as an antioxidant and has free hydroxyl groups that donate electrons to free radicals [6]. The in vitro and in vivo studies reported that HSP possesses antihypertensive, hypolipidemic, anti-inflammatory, and anticarcinogenic activities [7,8], and is widely used in different industries and cosmetic products [9]. Literature reported that the possible mechanism behind the antioxidant activity of HSP and its derivatives might be due to the increased antioxidant cellular defenses via the ERK/Nrf2 signaling pathway, along with its radical scavenging activity; whereas, the anti-inflammatory properties reducing the inflammatory targets including NF- $\mathrm{kB}$, iNOS, and COX-2, and the chronic inflammation markers $[8,10]$. The in vivo and in vitro study by Yeh et al., [11] reported that HSP suppressed the expression of TNF- $\alpha$, IL-1 $\beta$, IL-6, KC, MIP-2, MCP-1, and IL-12 and enhanced the production of IL-4 and IL-10 in mice lung lavage challenged with LPS. Interleukin-33 (IL-33), a member of IL-1 family, plays a vital role in different inflammatory diseases and cancer [12,13]. Blocking IL-33 could be a potential therapy that allow reducing cytokine-mediated malignant stem cell [13] as well as drug resistance [14].

Lipopolysaccharide (LPS) is commonly found in the cell wall of Gram-negative bacteria. It has been found that LPS stimulates the release and expression of inflammatory cytokines leading to an acute inflammatory response by activating the Toll-like receptor 4 (TLR4)-dependent pathway [15]. Binding of LPS to TLR4 activates the NF- $\mathrm{KB}$ and AP-1 signal transduction pathways via recruitment and activation of myeloid differentiation factor 88 expression, IL-1R kinase, TNFR associated factor 6 , and NADPH oxidase [16]. The improved effects of HSP on reducing hepatotoxicity effect in rats induced by LPS administration has been reported [17]. Therefore, substances capable of inhibiting endotoxin inflammation have recently gained immense attention. The present study aimed to determine the potential protective role of HSP against LPS-induced oxidative stress and inflammation using BALB/C mice in the in vivo and in vitro experiments involving MCF7 breast cancer cell line.

\section{Results}

\subsection{Free Radical Scavenging Activity}

2, 2-diphenyl-1-picrylhydrazyl (DPPH) is a free radical, which is stable at room temperature. It produces deep violet solution in organic solvents. DPPH is reduced in the presence of HSP molecules due to the presence of phenolic hydroxyl groups, resulting in decreased intensity of the colored solution. As presented in Figure 1, the antioxidant activities of HSP were monitored by using different concentrations. The results demonstrated an increased free radical scavenging activity in higher concentration along with concentration-dependent inhibition.

\subsection{Viability and Cytotoxicity Assay}

Viability was examined via MTT colorimetric assay of MCF-7 cancer cell lines after $24 \mathrm{~h}$ of exposure at various concentrations (Figure 2). Different concentrations were used and ranging from 20 to 300 $\mu \mathrm{M}$. The results illustrated that the treatment with HSP significantly inhibited the cell growth $(p \leq 0.05)$ and that the reduction was concentration-dependent. 


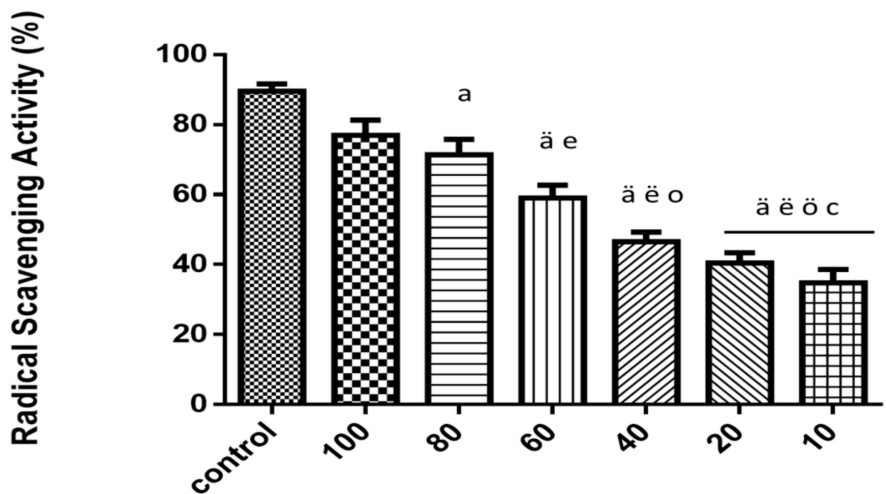

\section{Hesperidin Concentration $\left(\mu \mathrm{g} \mathrm{ml}^{-1}\right)$}

Figure 1. DPPH free radical scavenging activity of hesperidin (\%) at different concentrations (10-100 $\mu \mathrm{g} \mathrm{mL}^{-1}$ ). Data represent the means \pm standard error $(\mathrm{SE}), \mathrm{n}=10$. Control (vitamin c). ${ }^{\text {a Significant }}$

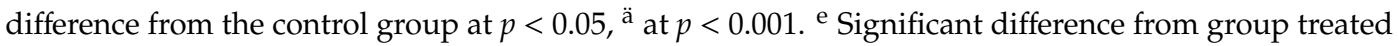
with $100 \mu \mathrm{g} \mathrm{mL}^{-1}$ at $p<0.05$, ${ }^{\ddot{\mathrm{e}}}$ at $p<0.001$. ${ }^{\circ}$ Significant difference from group treated with $80 \mu \mathrm{g} \mathrm{mL}^{-1}$ at $p<0.05,{ }^{\ddot{ }}$ at $p<0.01$. $^{\mathrm{c}}$ Significant difference from group treated with $60 \mu \mathrm{g} \mathrm{mL}^{-1}$ at $p<0.05$ (IC50 value $53.46 \mu \mathrm{g} \mathrm{ml}^{-1}$ ).

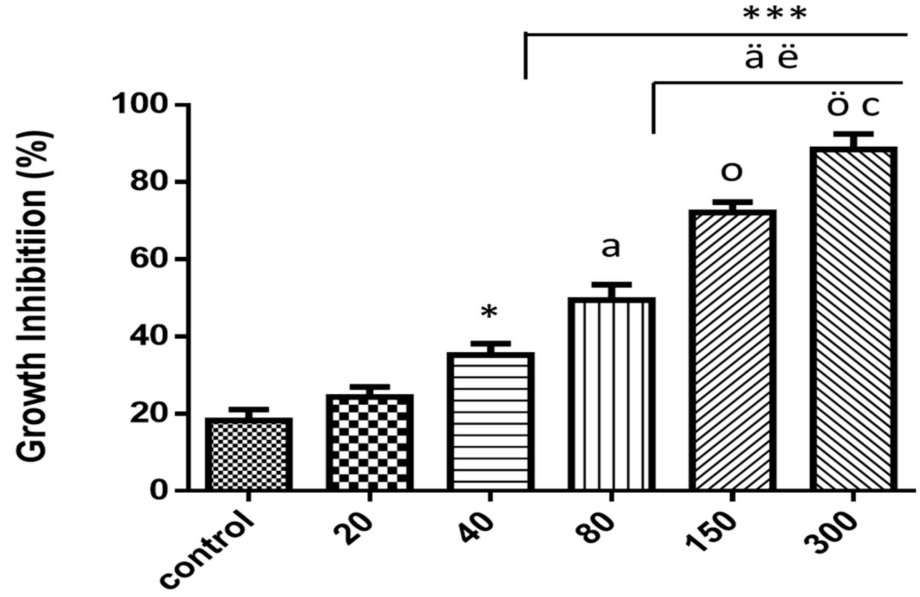

Hesperidin Concentration $(\mu \mathrm{M})$

Figure 2. Cytotoxicity effect of various concentrations $(0-300 \mu \mathrm{M})$ of hesperidin on MCF-7 breast cancer cell lines. Dose-dependent cytotoxicity effect of hesperidin was presented. Cells did not reveal significant cytotoxicity with lower dose at $24 \mathrm{~h}$ of exposure. ${ }^{*}$ Significant differences versus control at $p$ $<0.05,{ }^{* * *}$ at $p<0.001$. a Significant differences versus $20 \mu \mathrm{M}$ at $p<0.01,{ }^{\ddot{a}}$ at $p<0.001$. ё Significant differences versus $40 \mu \mathrm{M}$ at $p<0.01{ }^{\circ}$ significant differences versus $80 \mu \mathrm{M}$ at $p<0.01,{ }^{\circ}$ at $p<0.001$. c Significant differences between 150 NS $300 \mu \mathrm{M}$ at $p<0.05$. Data represent mean \pm SD of three independent experiments, each comprising duplicate cultures.

\subsection{Clonogenity Assay}

The result of clonogenity assay is presented in Figure 3. The reduced colony count of MCF-7 was highly significant in both concentrations used compared to that of the control group. The reduced clonogenic activity was measured by using Image-J software. Significant results $(p \leq 0.001)$ were observed at concentration of $40 \mu \mathrm{M}$ than those at $20 \mu \mathrm{M}$. 


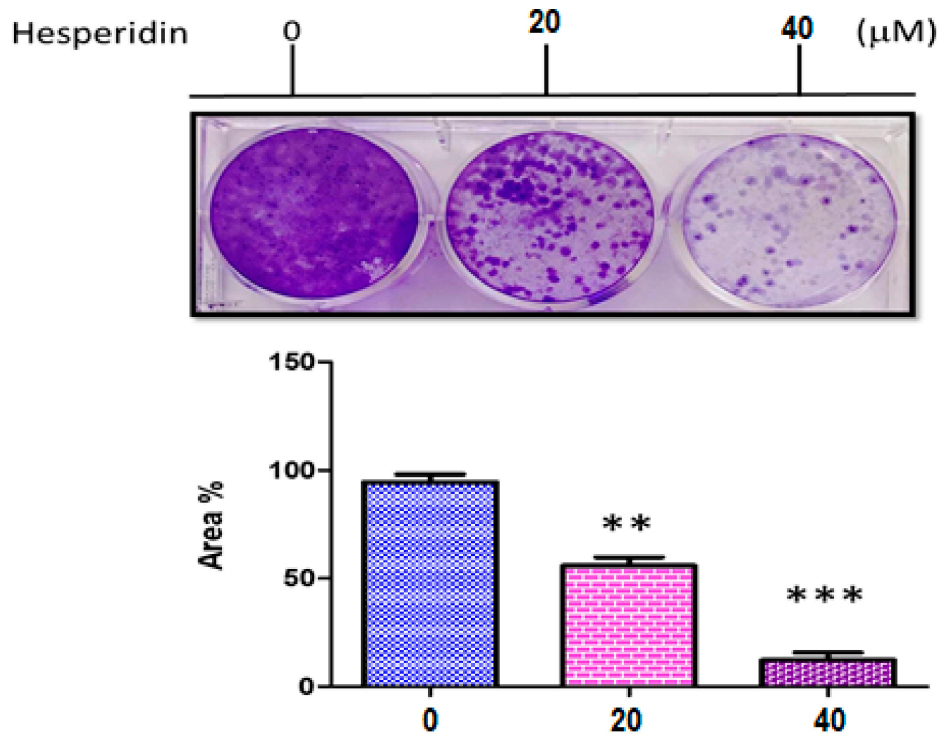

Hesperidin Concentration $(\mu \mathrm{M})$

Figure 3. Clonogenity assay of MCF-7 cancer cell line not treated (0), 20, and $40 \mu \mathrm{M}$ hesperidin (HSP). ** Significant differences versus control at $p<0.01, * *$ at $p<0.001$. Data represent mean $\pm \mathrm{SD}$ of three independent experiments, each comprising duplicate cultures.

\subsection{Apoptosis and Morphological Study using Sulforhodamine Staining}

To evaluate whether the cytotoxic effects were related to apoptosis or necrosis, the morphological changes were examined after treating the cells with HSP, as illustrated in Figure 4. The results indicated clear changes in the cell shape, which was associated with a later stage of apoptosis, including increased nuclear condensation and formation of apoptotic features.
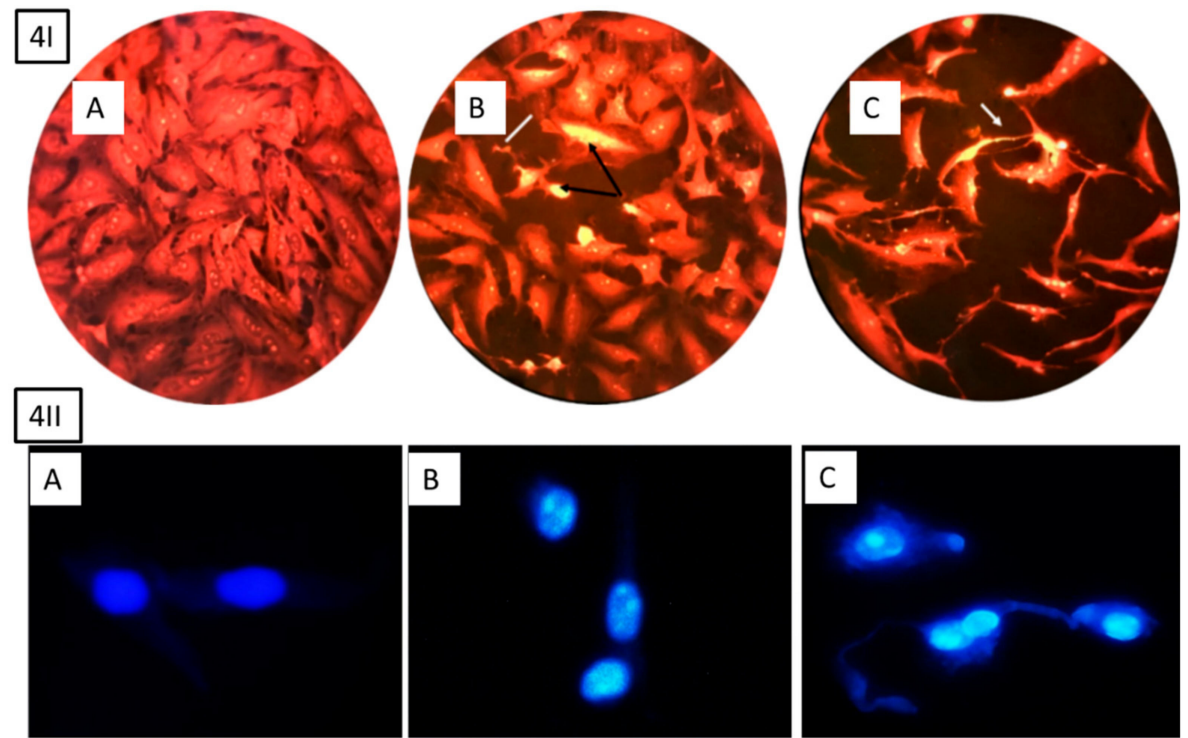

Figure 4. Morphological apoptosis of MCF-7 cells after treatment with hesperidin, 4I stained with sulforhodamine 101 and 4II cells stained with DAPI (20 and $\left.40 \mu \mathrm{g} \mathrm{ml}^{-1}\right)$. (A) Control cell has normal angular or polygonal shape with tact nucleus and is stained with a less bright fluorescence. (B) Treated cells with $20 \mu \mathrm{g} \mathrm{ml}^{-1}$ depict shrunken and condensed cytoplasm, chromatin (black arrow 4I), fragmentation, and apoptotic bodies (white line 4I). (C) Treated cells with $40 \mu \mathrm{g} \mathrm{ml}^{-1}$ clearly indicate late apoptosis including high cytoplasm and chromatin condensation, reduced cell count, and echinoid spikes on the surface of apoptotic cell (white arrow 4I). 


\subsection{Determination of Cytokine Levels}

Tables 1 and 2 present the hesperidin impact on IL-33 and TNF- $\alpha$ levels of spleen tissue in normal and LPS-induced inflammation mice. The results indicate that inflammation increased the cytokine secretion, as the levels of the both interleukins were significantly elevated $(P<0.05)$ in the LPS challenge group compared with the control group. In contrast, HSP treated mice presented an ameliorated anti-inflammatory reaction resulting in significantly decreased levels of IL-33 and TNF- $\alpha$ in mice that were cotreated with HSP and LPS; however, no significant effect was observed in the IL-33 and TNF- $\alpha$ levels in the mice injected with only HSP when compared to the control and cotreated mice.

Table 1. IL-33 level in spleen homogenate of mice injected hesperidin for five days and treated with or without lipopolysaccharide (LPS). Experiment was performed in duplicate.

\begin{tabular}{ccc}
\hline Treatment Groups & Dose Concentration & $\begin{array}{c}\text { IL-33 Level (Mean } \pm \text { SE) } \\
\text { (pgww }^{-1} \text { ) }\end{array}$ \\
\hline Control (DMSO + PBS) & $5 \mu \mathrm{g} \mathrm{ml}^{-1}$ & $40.582 \pm 8.043^{\#}$ \\
LPS only & $5 \mu \mathrm{g} \mathrm{ml}^{-1}$ & $225.13 \pm 13.20^{*}$ \\
Hesperidin only & $5 \mu \mathrm{g} \mathrm{kg}^{-1}$ & $43.78 \pm 14.72^{\#}$ \\
Hesperidin only & $10 \mu \mathrm{g} \mathrm{kg}^{-1}$ & $68.22 \pm 19.40^{\# ~ N S}$ \\
Hesperidin + LPS & $5 \mu \mathrm{gg} \mathrm{kg}^{-1}+5 \mu \mathrm{g} \mathrm{ml}^{-1}$ & $129.18 \pm 18.03^{* \# \mathrm{a}}$ \\
Hesperidin + LPS & $10 \mu \mathrm{g} \mathrm{kg}^{-1}+5 \mu \mathrm{g} \mathrm{ml}^{-1}$ & $102.09 \pm 14.20^{* \# \mathrm{a}}$ \\
\hline
\end{tabular}

$(*)$ indicate significant differences at $p<0.05$ versus control, (\#) indicate significant differences at $p<0.05$ versus LPS, (a) Significant $(p<0.05)$ between hesperidin versus hesperidin with LPS, (NS) not significant, $(p>0.05)$ between same hesperidin treatment groups with different concentration, (ww) wet weight.

Table 2. TNF- $\alpha$ level in spleen homogenate of mice injected hesperidin for five days and treated with or without LPS. Experiment was performed in duplicate.

\begin{tabular}{|c|c|c|}
\hline Treatment Groups & Dose Concentration & TNF- $\alpha$ Level (pg mg ww ${ }^{1}$ ) \\
\hline Control (DMSO + PBS) & $5 \mu \mathrm{g} \mathrm{ml}^{-1}$ & $119.56 \pm 9.81^{\#}$ \\
\hline LPS only & $5 \mu \mathrm{g} \mathrm{ml}^{-1}$ & $338.86 \pm 22.87$ * \\
\hline Hesperidin only & $5 \mu \mathrm{g} \mathrm{kg}^{-1}$ & $256.1 \pm 23.61^{\#}$ \\
\hline Hesperidin only & $10 \mu \mathrm{g} \mathrm{kg}^{-1}$ & $230.75 \pm 15.39$ \# NS \\
\hline Hesperidin + LPS & $5 \mu \mathrm{g} \mathrm{kg}^{-1}+5 \mu \mathrm{g} \mathrm{ml}^{-1}$ & $285.55 \pm 22.27$ *\# \\
\hline Hesperidin + LPS & $\mu \mathrm{g} \mathrm{kg}^{-1}+5 \mu \mathrm{g} \mathrm{ml}^{-1}$ & $267.73 \pm 13.27$ *\# NS \\
\hline
\end{tabular}

$\left(^{*}\right)$ indicate significant differences at $p<0.05$ with control, (\#) indicate significant differences at $p<0.05$ with LPS, (NS)

not significant $(p>0.05)$ between same hesperidin treatment groups with different concentration, (ww) wet weight.

\subsection{Determination of Catalase and Glutathione}

The liver total catalase level results (Figure 5) were significantly reduced in mice treated with LPS, whereas they significantly increased in the HSP-treated and cotreated groups. Moreover, no significant differences were observed between the HSP and control groups.

The liver total glutathione level results (Figure 6) were significantly reduced in mice treated with LPS, whereas they significantly increased in HSP-treated and co-treated groups. Although no significant differences were observed between the HSP and control groups, significant differences existed between the group treated with $10 \mathrm{mg}$ of HSP only and that with $5 \mathrm{mg}$ HSP and LPS. 


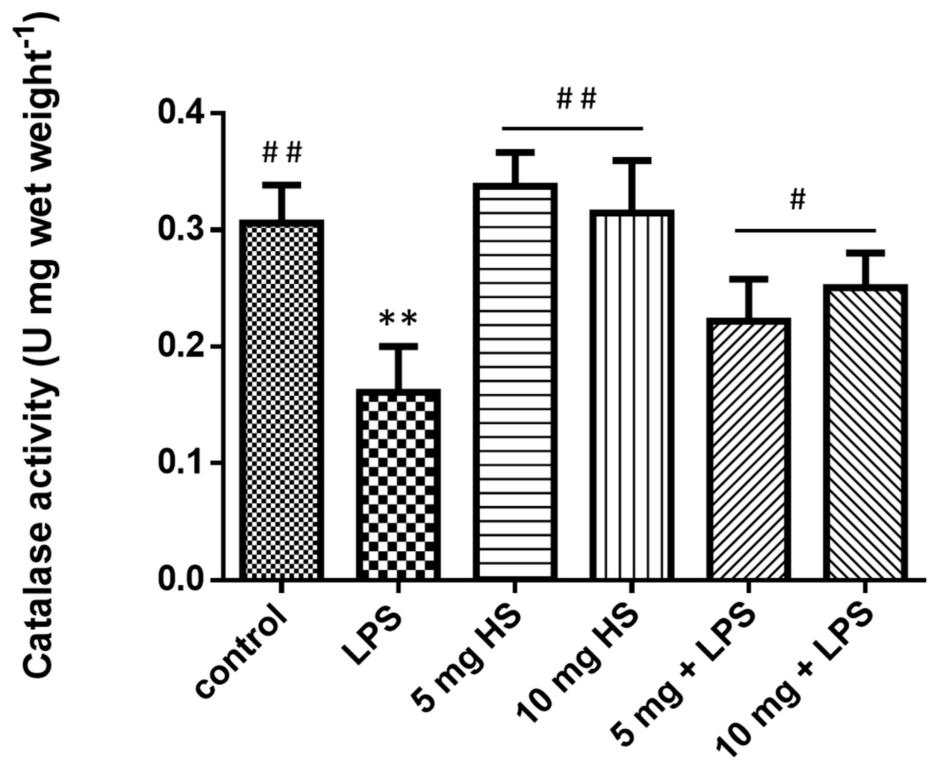

\section{Treatment Groups}

Figure 5. Treatment effects on the catalase activity in mice liver homogenate. Data represents the means \pm standard error (SE), $\mathrm{n}=10$. ${ }^{*}$ Significantly different from control group at $(p \leq 0.01)$; \# Significantly different from LPS group at $(p \leq 0.05),{ }^{\# \#}$ at $(p \leq 0.01)$.

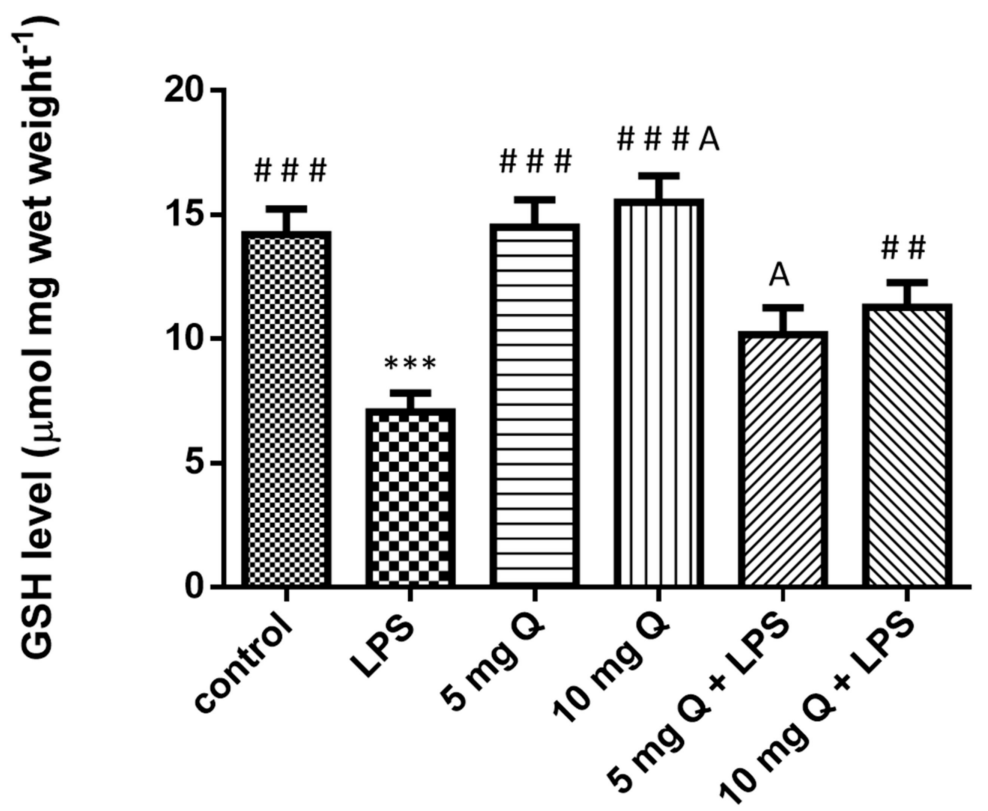

Treatment Groups

Figure 6. Treatment effects on the levels of glutathione level in mice liver homogenate. Data represent the means \pm standard error $(\mathrm{SE}), \mathrm{n}=10$. ${ }^{*}$ Significantly different from the control group; \# Significantly different from the LPS group, A significant difference between hesperidin $10 \mathrm{mg}$ versus hesperidin (5 $\mathrm{mg}+\mathrm{LPS})$. 


\section{Discussion}

The present study evaluated the protective effects of HSP against the potential toxic effects of LPS on male mice, by which the oxidative stress and inflammations were investigated. Oxidative stress represents imbalance between free radicals and antioxidants in the cells. Raetz and Whitfield [18] reported that oxidative stress occurs due to an abnormal production of free radicals ROS, which is one of the hepatotoxic agents caused by LPS. The increase in the production of free radicals causing fat oxidation loses cell membranes, which is an important cause of destruction and damage to the cell membrane [19]. Our previous study [20], demonstrated that the liver is a target of LPS oxidative damage, which led to a significant increase in malondialdehyed (MDA) in the homogenate mice liver as a marker of lipid peroxidation. Similarly, Kaur et al. [17] reported the improvement of hesperidin in (LPS) endotoxin-induced hepatotoxicity and oxidative stress in the liver of rats; suggested mechanisms by inhibition of cytotoxic effect of nitric oxide and free radicals ROS in particular.. The results of present study clearly demonstrated that LPS administration significantly decreased the level of GHS and CAT. In contrast, HSP treatment revealed tremendous reduction in the lipid peroxidation and increased the antioxidant system capacity, wherein the level of CAT enzyme and GSH significantly increased in the mice cotreated with LPS and HSP. These results confirm the finding that HSP has a strong free radical scavenging potential as observed in the DPPH assay results. Flavonoids contain hydroxyl groups, specifically those comprising O-dihydroxy in ring B that may play a pivotal role in root inhibition. They provide greater stability and are involved in the transport of electrons between the hydroxyl groups of ring B [21]. Therefore, flavonoids and polyphenols act potent inhibitors of free radicals due to the high interaction of their hydroxyl substitutes [22]. Few studies demonstrated that HSP protected the organ tissues against various toxic agents, which induced oxidative damage such as TCDD, cadmium, and dimethylbenzanthracene [23,24]. Different mechanisms have been suggested for the beneficial effects of HSP against LPS damage including its antioxidant ability or suppression of AhR receptors in the cells [25].

The proinflammatory cytokines investigated in this study are part of an important mediator of inflammation response presenting cellular activity such as cell proliferation and apoptosis [26]. In this study, the cytokines levels were significantly increased in the spleen tissue after treatment with LPS; however, HSP treatment significantly decreased the levels of interested cytokines and consequently reduced the inflammation effects. Previous studies $[27,28]$ reported the activated role of LPS in increased production of ROS from neutrophils and macrophages, consciously, increased the production of diverse inflammatory mediators which recruit more neutrophils to the tissue where inflammation process propagation. Therefore, it can be suggested that the protective effects of HSP moderated the inflammatory response along with antioxidant status against LPS-induced cytotoxicity in mice. In addition, it has been demonstrated that flavonoids inhibit the expression of proinflammatory genes in response to mediators like TNF- $\alpha$ and IL- $\beta 1[29,30]$. Thus, it can be suggested that the protective effect of HSP against LPS toxicity might be due to the decrease in the inflammatory cytokine levels. The protective effect of HSP against LPS toxicity might be due to the decrease in the inflammatory cytokine levels by the reduction in cytokines including TNF- $\alpha$ levels in stressed hepatocyte by which diminish significantly cell damages induced by LPS.

\section{Materials and Methods}

\subsection{Chemicals and Reagents}

Hesperidin ( $\geq 80 \%$ ), dimethyl sulfoxide (DMSO), and LPS (serotype E. Coli 0111:B4) liquid in PBS, (pH 7.4), DAPI (4', 6-diamidino-2-phenylindole) and sulforhodamine 101 were obtained from Sigma Aldrich Co. (St. Louis, MO, USA). Cytokine kits (IL-33 and TNF- $\alpha$ ) were purchased from Diaclone (Besancon Cedex, France). All other tissue culture chemicals and RPMI-1640 media of analytical grade were purchased from GIBCO (Rockville, MD, USA). 


\subsection{Animals and Experimental Design}

Male mice BALB/c (20-25g) were obtained and housed in the Animal House of Biological Department, College of Education for Pure Sciences/Ibn Al-Haitham, under controlled environmental conditions (12 light:12 dark light cycles; $25 \pm 2{ }^{\circ} \mathrm{C}$ temperature). Water and food were provided ad libitum. Animals were categorized into six groups, each comprising $10 \mathrm{mice}$, and were injected intraperitoneally (i.p.) with HSP for 4 days as following: Group I (negative control) received $100 \mu \mathrm{l}$ DMSO; Group II received $100 \mu \mathrm{l}$ LPS; Group III was injected with $5 \mathrm{mg} \mathrm{kg}^{-1} \mathrm{HSP}$; Group IV was administered $10 \mathrm{mg} / \mathrm{kg}$ HSP. Groups V and VI received 5 and $10 \mathrm{mg} \mathrm{kg}^{-1} \mathrm{HSP}$, respectively, followed by intraperitoneal injection with LPS $\left(50 \mu \mathrm{g} \mathrm{ml}^{-1}\right)$ for $90 \mathrm{~min}$.

\subsection{Hesperidin Antioxidant Activity Measurement}

The antioxidant activity was determined by using DPPH according to Al-Shmgani et al. [31]. Briefly, $1 \mathrm{~mL}$ of the samples was mixed with an equal volume of the DPPH solution $(60 \mu \mathrm{M})$. After 30 min incubation at $37^{\circ} \mathrm{C}$ in darkness, the absorbance was recorded at $517 \mathrm{~nm}$ spectrophotometrically (Perkin-Elmer Lambda 25, Germany). L-ascorbic acid was used as a positive control, and the measurements were carried out in triplicate. Inhibition of free radicals by DPPH was calculated by the following equation:

$$
\text { DPPH scavenging activity }(\%)=\mathrm{Ac}-\mathrm{As} / \mathrm{Ac} \times 100
$$

where, $\mathrm{Ac}=$ control absorbance and As = sample absorbance.

\subsection{Determination of Antioxidants}

Glutathione and catalase were determined in the liver homogenate according to the method by Sedlak and Lindsay [32]. The tissue was homogenized in PBS buffer at a ratio of $1 \mathrm{~g}$ tissue to $4 \mathrm{~mL}$ buffer, followed by centrifugation at $3000 \mathrm{rpm}$ for $10 \mathrm{~min}$ at $4{ }^{\circ} \mathrm{C}$. The supernatant was mixed with DTNB at 1:1 ratio. The absorbance was recorded at $415 \mathrm{~nm}$, and the results were calculated by the following equation:

$$
\text { Glutathione activity }\left(\mu \mathrm{mol} \mathrm{mg} \mathrm{wet} \text { weight }^{-1}\right)=(\mathrm{AB} / \mathrm{E}) * \mathrm{~L} / \mathrm{mg} \text { liver weight }
$$

$\mathrm{AB}=$ sample absorbance, $\mathrm{E} 1360, \mathrm{~L}=$ light length.

\subsection{Determination of Catalase}

Catalase activity was determined according to Huo et al. [33]. Briefly, $100 \mu$ of samples was added to $1.9 \mathrm{~mL}$ of phosphate buffer; thereafter, $1 \mathrm{~mL}$ of $\mathrm{H}_{2} \mathrm{O}_{2}$ was added to all samples and the absorbance was read at $240 \mathrm{~nm}$ for $3 \mathrm{~min}$.

\subsection{Determination of Cytokines}

Enzyme-linked immunosorbent assay (ELISA) was used to determinate the proinflammatory cytokines (Interleukin-33 (IL-33) and TNF- $\alpha$ ) from spleen homogenate by using the available commercial kits. The assay was carried out according to the manufacturer's instructions.

\subsection{Cell Culture}

The MCF7 breast cancer cell line was provided by the Center of Biotechnology at AL-Nahrain University. RPMI-1640 medium containing 10\% fetal bovine serum (FBS), $1 \%$ antibiotic (containing 10,000 $\mathrm{U} \mathrm{ml}^{-1}$ penicillin $\mathrm{G}, 10 \mathrm{mg} \mathrm{ml}^{-1}$ streptomycin, and $25 \mathrm{\mu g} \mathrm{ml}^{-1}$ amphotericin B) was used in the cell culture and for maintenance. Cells were incubated at $37^{\circ} \mathrm{C}$ in humidified $5 \% \mathrm{CO}_{2}$ and were cultured at a concentration of $2.5 \times 10^{5}$ cells ml ${ }^{-1}$ [34]. 


\subsection{Measurement of Cell Viability}

The colorimetric cell viability 3-(4,5-dimethylthiazol-z-yl)-2,5-diphenyltetrazolium (MTT) assay was used, as described by Berridge et al. [35]. Cells were seeded in 96-well plates at a concentration of $1 \times 10^{5}$ cell ml ${ }^{-1}$; thereafter, HSP was added at concentrations of 10, 20, 40, 60, 80, and $100 \mu \mathrm{g} \mathrm{ml}^{-1}$. Culture in the medium served only as a control. The absorbance was measured at $620 \mathrm{~nm}$ using an enzyme-linked immunosorbent assay (ELISA) reader (VersaMaxTM, Molecular Devices, Sunnyvale, CA). Percentage of the inhibition ratio was calculated according to the following formula:

$$
\mathrm{GI} \%=((O D \text { of control wells }-O D \text { of control test wells }) / O D \text { of control wells }) \times 100
$$

where GI = growth index and OD = optical density.

\subsection{Clonogenity Assay}

The clonogenic cells were assayed according to the method of Liu, with certain modifications [36]. The cells were plated at a density of $10^{4}$ cells/well in 24 multiwell culture plates, and were then treated with 20 and $40 \mu \mathrm{M}$ of HSP. After $24 \mathrm{~h}$ of treatment, the surviving cells were trypsinized, enumerated, and plated in Petri dishes at $5 \times 10^{3}$ cells/well with a fresh medium. Cells colonies were fixed, stained with crystal violet for $30 \mathrm{~min}$, and were then washed with tap water. Cells were then imaged with a digital camera and the clonogenic cells were determined as those able to form a colony with at least 50 cells.

\subsection{Morphological Evaluation of Apoptotic Cells}

The combine of DAPI with sulforhodamine SR 101 was used [37] to evaluate the apoptotic features of cells. Fluorescent microscopy was used for this purpose (excitation/emission 358/461 nm for DAPI; $586 / 605 \mathrm{~nm}$ for sulforhodamine 101). MCF-7 cells were cultured in 96 multiwell plates at a density of $1 \times 10^{4}$. After confluence monolayer, the cells were exposed to 20 and $40 \mu \mathrm{g} \mathrm{ml} \mathrm{m}^{-1}$ hesperidin for 24 $\mathrm{h}$, and were then incubated at $37{ }^{\circ} \mathrm{C}$ with $5 \% \mathrm{CO}_{2}$. Control cells were treated only with the media. Post-incubation, the media were removed, and the cells were washed twice with PBS. For fixative 1 $\mathrm{mL}$ of $96 \%$ ethanol for $30 \mathrm{~min}$ was added and left to air-dry at $25^{\circ} \mathrm{C}$. Stained with sulforhadamine 101-DAPI solution (prepared by mixing equal volumes of Sulforhodamine101 and DAPI solutions) was added for $30 \mathrm{~min}$ and left to air-dried. Then washed with PBS and covered with a cover-slip. The cells were examined immediately under a fluorescence microscope at 100× magnification power.

\subsection{Statistical Analysis}

Statistical analysis was performed using SPSS software version 16.0. All results were presented as means \pm standard error. Significance was calculated using one-way analysis of variance (ANOVA), followed by Tukey's test. A value of $p<0.05$ was considered as statistically significant.

\section{Conclusions}

In conclusion, the present study determined the oxidative stress and immune-toxic effects of LPS. The use of HSP reduced these negative effects by decreased levels of TNF- $\alpha$ and IL- $\beta 1$ in the spleen tissue, and increased the antioxidant levels including CAT and GSH along with anticancer properties. Hence, HSP can be a promising potential medicinal agent.

Author Contributions: Conceptualization, methodology, R.A.-R., H.A.-S.; validation, H.A.-S., Y.H.D., and S.E.-H.; investigation and data curation, R.A.-R. and H.A.-S.; writing-original draft preparation, R.A.-R. and H.A.-S.; writing-review and editing, Y.H.D. and S.E.-H.; supervision, H.A.-S. and Y.H.D.; funding acquisition Y.H.D. and S.E.-H.. All authors have read and agreed to the published version of the manuscript.

Funding: The authors extend their appreciation to the University of Baghdad/ College of Ibn-al Haithem and to the Deanship of Scientific Research at King Saud University for funding this work through research group NO (RGP-1438-012). 
Acknowledgments: The authors extend their appreciation to University of Baghdad and to the Researchers Support \& Services Unit (RSSU) for their technical support.

Conflicts of Interest: The authors declare no conflict of interest.

\section{References}

1. Panche, A.N.; Diwan, A.D.; Chandra, S.R. Flavonoids: An overview. J. Nutr. Sci. 2016, 5, e47. [CrossRef]

2. Hajialyani, M.; Hosein Farzaei, M.; Echeverría, J.; Nabavi, S.M.; Uriarte, E.; Sobarzo-Sánchez, E. Hesperidin as a neuroprotective agent: A review of animal and clinical evidence. Molecules 2019, 24, 648. [CrossRef]

3. Jiao, Q.; Xu, L.; Jiang, L.; Jiang, Y.; Zhang, J.; Liu, B. Metabolism study of hesperetin and hesperidin in rats by UHPLC-LTQ-Orbitrap MS. Xenobiotica 2019, 57, 1-27. [CrossRef] [PubMed]

4. Rahal, A.; Kumar, A.; Singh, V.; Yadav, B.; Tiwari, R.; Chakraborty, S.; Dhama, K. Oxidative Stress, Prooxidants, and Antioxidants: The Interplay. BioMed Res. Int. 2014, 2014, 1-19. [CrossRef] [PubMed]

5. Grivennikov, S.I.; Karin, M. Inflammation and oncogenesis: A vicious connection. Curr. Opin. Genet. Dev. 2010, 20, 65-71. [CrossRef]

6. Kumar, S.; Pandey, A.K. Chemistry and biological activities of flavonoids: An overview. Sci. World J. 2013, 2013, 1-16. [CrossRef]

7. Parhiz, H.; Roohbakhsh, A.; Soltani, F.; Rezaee, R.; Iranshahi, M. Antioxidant and anti-inflammatory properties of the citrus flavonoids hesperidin and hesperetin: An updated review of their molecular mechanisms and experimental models. Phytother. Res. 2014, 29, 323-331. [CrossRef]

8. Garg, A.; Garg, S.; Zaneveld, L.J.D.; Singla, A.K. Chemistry and pharmacology of the citrus bioflavonoid hesperidin. Phytother. Res. 2001, 15, 655-669. [CrossRef]

9. Shan, Y. Comprehensive Utilization of Citrus By-products; Academic Press: Cambridge, MA, USA, 2016.

10. Rice-Evans, C.A.; Miller, N.J. Structure-antioxidant activity relationships of flavonoids and phenolic acids. Free Radic. Biol. Med. 1996, 20, 933-956. [CrossRef]

11. Yeh, C.C.; Kao, S.J.; Lin, C.C.; Wang, S.D.; Liu, C.J.; Kao, S.T. The immunomodulation of endotoxin-induced acute lung injury by hesperidin in vivo and in vitro. Life Sci. 2007, 80, 1821-1831. [CrossRef]

12. Cayrol, C.; Girard, J.P. IL-33: An alarmin cytokine with crucial roles in innate immunity, inflammation and allergy. Curr. Opin. Immunol. 2014, 31, 31-37. [CrossRef] [PubMed]

13. Rössle, M.; Cathomas, G.; Bonapace, L.; Sachs, M.; Dehler, S.; Storz, M.; Huber, G.; Moch, H.; Junt, T.; Mertz, K.D. Interleukin-33 expression indicates a favorable prognosis in malignant salivary gland tumors. Int. J. Surg. Pathol. 2016, 24, 394-400.

14. Corbin, A.S.; Agarwal, A.; Loriaux, M.; Cortes, J.; Deininger, M.W.; Druker, B.J. Human chronic myeloid leukemia stem cells are insensitive to imatinib despite inhibition of BCR-ABL activity. J. Clin. Investig. 2011, 121, 396-409. [CrossRef] [PubMed]

15. Levescot, A.; Flamant, S.; Basbous, S.; Jacomet, F.; Feraud, O.; Anne Bourgeois, E.; Bonnet, M.-L.; Giraud, C.; Roy, L.; Barra, A. BCR-ABL-induced deregulation of the IL-33/ST2 pathway in CD34(+) progenitors from chronic myeloid leukemia patients. Cancer Res. 2014, 74, 2669-2676. [CrossRef]

16. Guo-Ge, P.; Zhong-Hai, L.; Jie, B.; Hai-Yan, Z. Literature review of researches on physiological effects of hesperidin. Nonwood For. Res. 2006, 4, 18.

17. Kaur, G.; Tirkey, N.; Chopra, K. Beneficial effect of hesperidin on lipopolysaccharide-induced hepatotoxicity. Toxicology 2006, 226, 152-160. [CrossRef]

18. Raetz, C.R.; Whitfield, C. Lipopolysaccharide endotoxins. Ann. Rev. Biochem. 2002, 71, 635-700. [CrossRef]

19. Brent, J.A.; Rumack, B.H. Mechanisms role of free radicals in toxic hepatic injury. Free Rad. Biochem. Clin. Toxicaol. 1993, 31, 139-171.

20. Al-Rikabi, R.F.; Al-Shmgani, H.S. Evaluation of hesperidin protective effect on lipopolysaccharide-induced inflammation and lipid peroxidation in BALB/c male mice. RJPT 2018, 11, 5513-5516. [CrossRef]

21. Fauconneau, B.; Waffo-Teguo, P.; Huguet, F.; Barrier, L.; Decendit, A.; Merillon, J.M. Comparative study of radical scavenger and antioxidant properties of phenolic compounds from Vitis vinifera cell cultures using in vitro tests. Life Sci. 1997, 61, 2103-2110. [CrossRef]

22. Procházková Bousova, I.; Wilhelmova, N. Antioxidant and prooxidant properties of flavonoids. Fitotrapia 2011, 82, 513-523. [CrossRef] [PubMed] 
23. Gonzalez-Molina, E.; Dominguez-Perles, R.; Moreno, D.A.; Garcfa-Viguera, C. Natural bioactive compounds of citrus lemon for food and health. J. Pharm. Biomed. Anal. 2010, 51, 327-345. [CrossRef] [PubMed]

24. Pari, L.; Shagirtha, K. Hesperetin protects against oxidative stress related hepatic dysfunction by cadmium in rat. Exp. Toxicol. Pathol. 2012, 64, 513-520. [CrossRef] [PubMed]

25. Yang, Y.L.; Hsu, H.T.; Wang, K.H.; Wang, C.S.; Chen, C.M.; Ko, W.C. Hesperidin-3-o-methylether is more potent than hesperidin in phosphodiesterase inhibition and suppression of ovalbumin-induced airway hyperreponsiveness. Evid. Based Complement. Alternat. Med. 2012, 908562.

26. Mukherjee, S.; Chen, L.-Y.; Papadimos, T.J.; Huang, S.; Zuraw, B.L.; Pan, Z.K. Lipopolysaccharide-driven Th2 cytokine production in macrophages is regulated by both MyD88 and TRAM. J. Biol. Chem. 2009, 284, 29391-29398. [CrossRef]

27. Rotimi, S.O.; Bankole, G.E.; Adelani, I.B.; Rotimi, O.A. Hesperidin prevents lipopolysaccharide-induced endotoxicity in rats. Immunopharmacol. Immunotoxicol. 2016, 38, 364-371. [CrossRef]

28. Kalliolias, G.D.; Gordon, R.A.; Ivashkiv, L.B. Suppression of TNF- $\alpha$ and IL-1 signalling identifies a mechanism of homeostatic regulation of macrophages by IL-17. J. Immunol. 2010, 185, 7047-7056. [CrossRef]

29. Park, H.H.; Lee, S.; Son, H.Y.; Park, S.B.; Kim, M.S.; Chio, E.J.; Singh, T.S.; Ha, J.H.; Lee, M.G.; Kim, J.E.; et al. Flavonoids inhibit histamine release and expression of proinflammatory cytokines in mast cells. Arch. Pharm. Res. 2008, 31, 1303-1311. [CrossRef]

30. Wei, D.C.X.; Chu, X.; Wei, M.; Hua, S.; Deng, X. Hesperidin suppresses ovalbumin induced airway inflammation in a mouse allergic asthma model. Inflammation 2012, 35, 114-121. [CrossRef]

31. Al-Shmgani, H.S.; Mohammed, W.H.; Sulaiman, G.M.; Saadon, A.H. Biosynthesis of silver nanoparticles from Catharanthus roseus leaf extract and assessing their antioxidant, antimicrobial and wound healing activity. Artif. Cell Nanomed. Biotechnol. 2016, 45, 1-7. [CrossRef]

32. Sedlak, J.; Lindsay, R.H. Estimation of total protein bound and non-protein sulfhydryl groups in tissue with Ellmans reagent. Anal. Biochem. 1968, 25, 192-205. [CrossRef]

33. Huo, H.; Wang, B.; Liang, Y.K.; Bao, Y.; Gu, Y. Hepatoprotective and antioxidant effect of licorice extract against CCL4 induced oxidative damage in rat. Int. J. Mol. Sci. 2011, 12, 6529-6543. [CrossRef] [PubMed]

34. Al-Shmgani, H.S.; Moate, R.; Macnaughton, P.; Sneyd, J.R.; Moody, A.J. Effect of hyperoxia on permeability of 16HBE14o-cell monolayer: The protective role of antioxidant vitamins E and C. FEBS J. 2013, 280, 4512-4521. [CrossRef] [PubMed]

35. Berridge, M.V.; Herst, P.M.; Tan, A.S. Tetrazolium dyes as tools in cell biology: New insights into their cellular reduction. Biotechnol. Ann. Rev. 2005, 11, 127-152.

36. Taha, H.R. Effect of crude extracts of Melia azedarach on cancer and normal cell line (in vitro). Master's Thesis, University of Al-Nahrian, Baghdad, Iraq, 2007.

37. Stöhr, M.; Goerttler, K. The Heidelberg flow analyzer and sorter (HEIFAS) approach on the prescreening of uterine cancer. J. Histochem. Cytochem. 1979, 27, 564-566. [CrossRef]

Sample Availability: Samples of the compounds are not available from the authors.

(C) 2020 by the authors. Licensee MDPI, Basel, Switzerland. This article is an open access article distributed under the terms and conditions of the Creative Commons Attribution (CC BY) license (http://creativecommons.org/licenses/by/4.0/). 